\title{
Assessment of nutritional status of children and adolescents with Spastic Quadriplegic Cerebral Palsy
}

\author{
Thaisa Barboza CASELLI, Elizete Aparecida LOMAZI, Maria Augusta Santos MONTENEGRO and \\ Maria Angela BELLOMO-BRANDÃO
}

ABSTRACT - Background - Due to several factors, such as gastrointestinal's diseases and difficulty in feeding, children with Spastic Quadriplegic Cerebral Palsy tend to present nutritional deficits. Objective - To assess the nutritional status of pediatric patients with Spastic Quadriplegic Cerebral Palsy according to reference curves for this population and with the measures of folds and circumferences, obtained by the upper arm circumference and triceps skin fold. Methods - The data were obtained from: knee-height, estimated height, weight, upper arm circumference, and triceps skin fold. Values of folds and circumferences were compared with Frisancho, and specific curves for these patients were used as reference. The relationship between the values in the growth curve for healthy children, Z-Score, and comparison with the reference curve were verified by Fisher's exact test. We adopted the significance level of $5 \%$. Results - We evaluated 54 patients. The mean age was 10.2 years, and 34 were male, 25 fed by gastrostomy and 29 , orally. The frequency of low weight by the reference curve was $22.22 \%$. More than half of the patients presented the parameters indicating lean mass below the 5 th percentile. The height of all patients was classified as adequate for the age by the reference curve. Conclusion - Low weight was found in $22 \%$ of patients, and there is a greater tendency to present reduced muscle mass and increased fat mass, showing the need for evaluation and appropriate interventions for patients with Spastic Quadriplegic Cerebral Palsy.

HEADINGS - Cerebral palsy. Quadriplegia. Nutrition assessment.

\section{INTRODUCTION}

Spastic Quadriplegic Cerebral Palsy (SQCP) designates a type of not progressive or evolutionary chronic encephalopathy (NECE), associated with serious motor abnormalities, usually poor dietary intake, impairment of body composition, and malnutrition. It is a permanent, severe, and irreversible neurological condition $^{(6,9,23)}$.

Many children with SQCP present swallowing disorders and other diseases of the gastrointestinal tract (GIT), as gastroesophageal reflux and constipation ${ }^{(6,9,23,26)}$. In general, they are unable to communicate hunger and satiety, which makes it necessary to caregivers to regulate the supply and intake randomly ${ }^{(13)}$. As the task of feeding these patients is time-consuming, laborious, and with risk of tracheal suction, the quantity of food supplied may be insufficient to meet individual demands ${ }^{(13,14)}$. These factors contribute for many children with cerebral palsy to present impairment of the nutritional status.

Fung et al. (2002), in their study with 230 children with moderate/severe $\mathrm{CP}$, observed that the feeding difficulty is common and often associated with the nutritional status. Even those who presented moderate dysfunction tend to require cropped and smashed food, which may be a risk to the maintenance of an adequate nutritional status ${ }^{(9)}$.
The anthropometric assessment in children with SQCP requires differentiated procedures, and the ideal anthropometric goals are different from those expected in healthy children ${ }^{(1,2,3,5,17,18,20)}$.

Brooks et al. built, in 2011, specific growth curves for children with CP based on the curves of the Centers for Disease Control and Prevention (CDC), considering degree of motor impairment and feeding way ${ }^{(2)}$. These curves represent the most current reference available, in addition of coming from a study with representative sample. Araújo and Silva (2013) analyzed patients with $\mathrm{CP}$ and found that $51 \%$ were below the 10th percentile of weight for age when placed in the CDC curves, while only $10 \%$ remained on this range when the data were plotted in the specific growth curves for cerebral palsy, indicating that references commonly used in pediatrics tend to overestimate the malnutrition in patients with $\mathrm{SQCP}^{(1)}$.

Several studies present data compatible with a high percentage of malnutrition in patients with SQCP(3,16,21,22,23). Stevenson (2006) verified that up to $19 \%$ of patients may be below the 10 th percentile of weight for age ${ }^{(22)}$. Samson-Fang and Stevenson (2000) found values of weight/height below the 10th percentile in $45 \%$ of the studied children ${ }^{(21)}$. Caram et al. (2010) identified $50.9 \%$ of malnutrition in the weight for age parameter ${ }^{(3)}$. However, the studies mentioned above have as limitation the fact that they examined patients with various types of $\mathrm{CP}$. 
Spastic quadriplegia is the more severe type of cerebral palsy ${ }^{(6)}$, because, in addition to global paralysis, convulsive syndrome, and respiratory complications, it is often associated with dysfunctional feeding $^{(11,25)}$, an aggravating factor for malnutrition ${ }^{(6,9,23)}$. This study was designed to describe the values relating to the nutritional assessment of children with Spastic Quadriplegic Cerebral Palsy (SQCP), followed on a tertiary care service, using specific references to this condition.

\section{METHODS}

This study was carried out in a university hospital, from April 2013 to March 2014. It was approved by the Ethics Committee on Institutional Research of Faculdade de Ciências Médicas of UNICAMP under the protocol number 331,270 in July 10, 2013.

The informed consent form was presented for agreement and signed by the guardians who agreed to participate.

Inclusion criteria were: age between two and nineteen years old and definitive diagnosis of Spastic Quadriplegic Cerebral Palsy. We excluded patients with genetic diseases.

Data on gender, age, etiology of $\mathrm{CP}$, and comorbidities related to gastrointestinal tract were obtained from medical records. The measurement of anthropometric parameters was performed on the patients' appointment date, according to the hospital's agenda. We used the following techniques and measures:

Estimated height: method used for patients unable to keep standing posture for direct height measure. To do so, we use the value of knee-height, measured with a Cescorf ${ }^{\circledR}$ bone caliper and the child's leg at an angle of $90^{\circ}$. The measurement of the length of the anterior surface of the leg until the sole was measured and applied to the formulas of Stevenson (1995) ${ }^{(23)}$ and Chumlea $(1994)^{(4)}$. Stevenson's equation was used for ages under 12 and Chumlea's equation, for ages over 12, as described in the Figure 1.

\begin{tabular}{|c|c|c|}
\hline Group & $\begin{array}{c}\text { Age } \\
\text { years })\end{array}$ & Equation \\
\hline Children* & $\begin{array}{c}2-12 \\
\text { years old }\end{array}$ & $\mathrm{EH}(\mathrm{cm})=24.2+(2.69 \times \mathrm{KH}) \pm 1.1(\mathrm{SD})$ \\
\hline $\begin{array}{c}\text { White } \\
\text { boy** }\end{array}$ & $\begin{array}{c}6-18 \\
\text { years old }\end{array}$ & $\mathrm{EH}(\mathrm{cm})=40.54+(2.22 \times \mathrm{KH})$ \\
\hline $\begin{array}{c}\text { Black } \\
\text { boy** }\end{array}$ & $\begin{array}{c}6-18 \\
\text { years old }\end{array}$ & $\mathrm{EH}(\mathrm{cm})=39.6+(2.18 \times \mathrm{KH})$ \\
\hline $\begin{array}{c}\text { White } \\
\text { girl** }\end{array}$ & $\begin{array}{c}6-18 \\
\text { years old }\end{array}$ & $\mathrm{EH}(\mathrm{cm})=43.21+(2.15 \times \mathrm{KH})$ \\
\hline $\begin{array}{c}\text { Black } \\
\text { girl** }\end{array}$ & $\begin{array}{c}6-18 \\
\text { years old }\end{array}$ & $\mathrm{EH}(\mathrm{cm})=46.59+(2.02 \times \mathrm{KH})$ \\
\hline $\begin{array}{c}\text { White } \\
\text { man** }\end{array}$ & $\begin{array}{c}>18 \\
\text { years old }\end{array}$ & $\mathrm{EH}(\mathrm{cm})=71.85+(1.88 \times \mathrm{KH})$ \\
\hline $\begin{array}{c}\text { Black } \\
\text { man** }\end{array}$ & $\begin{array}{c}>18 \\
\text { years old }\end{array}$ & $\mathrm{EH}(\mathrm{cm})=73.42+(1.79 \times \mathrm{KH})$ \\
\hline $\begin{array}{c}\text { White } \\
\text { woman** }\end{array}$ & $\begin{array}{c}>18 \\
\text { years old }\end{array}$ & $\mathrm{EH}(\mathrm{cm})=70.25+(1.87 \times \mathrm{KH})-(0.06 \times$ age $)$ \\
\hline $\begin{array}{c}\text { Black } \\
\text { woman** }\end{array}$ & $\begin{array}{c}>18 \\
\text { years old }\end{array}$ & $\mathrm{EH}(\mathrm{cm})=68.10+(1.86 \times \mathrm{KH})-(0.06 \times$ age $)$ \\
\hline
\end{tabular}

FIGURE 1. Mathematical equations for calculation of estimated height $(\mathrm{EH})$, from values obtained from knee-height $(\mathrm{KH})$, according to references of $*$ Chumlea et al. (1994) $)^{(4)}$ and $* *$ Stevenson $(1995)^{(23)}$. SD: Standard Deviation.
Weight: the Filizola ${ }^{\circledR}$ digital scale was calibrated to zero. Due to the impossibility of the patients to stand up, we first weighed the caregivers barefoot, with light clothes, and in standing position. Then, the children were weighted on their guardians' lap, and their weights were calculated by the difference.

Upper arm circumference (UAC): the children's arm was placed in flexion position. Using an inelastic tape measure, the midpoint between the acromial process of the scapula and the olecranon (elbow) was marked with felt-tip pen. Thus, the arm perimeter was measured with the pending member at the marked point.

Triceps skin fold (TSF): Lange ${ }^{\circledR}$ adipometer was applied on the back of the arm, in the same point used to obtain the UAC. The measurement was carried out following the longitudinal axis of the member.

The anthropometric measurements were measured on the right side of the child, and we considered the mean of three consecutive measurements. Later, we calculated values of Body Mass Index (BMI), Upper Arm Muscle Circumference (UAMC), Upper Arm Muscle Area (UAMA), and Upper Arm Fat Area (UAFA), using mathematical equations for these purposes (Figure 2). The values of folds and circumferences were compared with the reference of Frisancho (1993) $)^{(7)}$.

\begin{tabular}{|l|l|}
\hline Parameter & Equation \\
\hline BMI, $\left(\mathrm{Kg} / \mathrm{m}^{2}\right)$ & BMI, $\left(\mathrm{Kg} / \mathrm{m}^{2}\right)=\frac{\text { Weight }}{\text { Height }^{2}}$ \\
\hline UAMC $(\mathrm{cm})$ & UAMC $(\mathrm{cm})=\mathrm{UAC}(\mathrm{cm})-\pi \times[\operatorname{SQCP}(\mathrm{mm}) \div 10]$ \\
\hline UAMA $\left(\mathrm{cm}^{2}\right)$ & Male $\quad \operatorname{UAMA}\left(\mathrm{cm}^{2}\right)=\frac{[\mathrm{UAC}(\mathrm{cm})-\pi \times \mathrm{SQCP}(\mathrm{mm}) \div 10]^{2}-6.5}{4 \pi}$ \\
\hline UAFA $\left(\mathrm{cm}^{2}\right)$ & UAFA $\left(\mathrm{cm}^{2}\right)=\frac{\mathrm{UAC}(\mathrm{cm}) \times[\mathrm{SQCP}(\mathrm{mm}) \div 10]-\pi \times \frac{[\mathrm{SQCP}(\mathrm{mm}) \div 10]^{2}}{2}}{4}$ \\
\hline
\end{tabular}

FIGURE 2. Mathematical equations for body mass index (BMI) calculation, Upper Arm Muscle Circumference (UAMC), Upper Arm Muscle Area (UAMA), and Upper Arm Fat Area (UAFA), based on data of Upper Arm Circumference (UAC) and Triceps Skin Fold (TSF).

The curves of Brooks et al. (2011) (2) were used as reference standard. We defined as malnourished patients with index of weight for age below the 25 th percentile, as well as established in the original study. We considered the degree of motor impairment according to the division of the curves in the original study, in which all children belonged to level $\mathrm{V}$ by being patients with extremely committed self-mobility, being carried by manual wheelchair. We also considered the feeding way, since the study was composed of patients fed orally and by gastrostomy. We also used the reference curves of the World Health Organization (WHO) ${ }^{(27)}$ to calculate the Z-Score and compare the curves. We defined as eutrophic those that presented Z-Score $\geq 2 \mathrm{SD}$ and $\leq 1 \mathrm{SD}$, as thin those with Z-Score $<-2 \mathrm{SD}$, and obese those with Z-Score $>+2$ SD.

For tabulation and data analysis, we used the Statistical Package for the Social Sciences ${ }^{\circledR}$ software (SPSS), version 17.0. Exploratory data analysis was performed by descriptive statistics and summary measures (frequency, percentage, mean, standard deviation, mini- 
mum, median, and maximum). The relation between growth curve for healthy children (represented by the calculated Z-Score) and curve adopted as a reference was verified by Fisher's exact test. We adopted the significance level of $5 \%$.

\section{RESULTS}

We evaluated 54 pediatric patients with definitive diagnosis of SQCP, established by the team of Pediatric Neurology, 34 of them being male and 20, female. The age ranged from 2 to 18 years old, with a mean of 10.2 years \pm 4.45 , and median of 10.3 years. Twenty five patients were fed by gastrostomy (SGT) and 29 orally (O), and, for each group, the specific growth curves for the corresponding cerebral palsy were used ${ }^{(2)}$. All the children performed the estimated height and were able to undergo the knee-height measurement correctly.

Table 1 shows the analysis of the assessed anthropometric parameters. A total of $72.22 \%$ of the patients were classified as eutrophic for BMI and 100\% presented adequate height for

TABLE 1. Frequency and percentage of anthropometric variables of weight/age, height/age, BMI/age, skin folds, and upper arm circumferences in patients with Cerebral Palsy classified according to the reference curve of Brooks et al. ${ }^{(2)}$ and Frisancho ${ }^{(7)}$.

\begin{tabular}{|c|c|c|}
\hline \multirow{2}{*}{ Variables } & \multicolumn{2}{|c|}{ Individuals $(n=54)$} \\
\hline & $\mathrm{n}$ & $\%$ \\
\hline \multicolumn{3}{|c|}{ Weight for age } \\
\hline$<\mathrm{p} 5$ & 5 & 9.26 \\
\hline p10 - p90 & 45 & 83.33 \\
\hline$>\mathrm{p} 90$ & 4 & 7.41 \\
\hline \multicolumn{3}{|c|}{ Height for age } \\
\hline p10 - p90 & 51 & 94.44 \\
\hline$>\mathrm{p} 90$ & 3 & 5.56 \\
\hline \multicolumn{3}{|l|}{ BMI for age } \\
\hline$<\mathrm{p} 5$ & 12 & 22.22 \\
\hline p10 - p90 & 39 & 72.22 \\
\hline$>\mathrm{p} 90$ & 3 & 5.56 \\
\hline \multicolumn{3}{|c|}{ Upper arm circumference } \\
\hline$<\mathrm{p} 5$ & 28 & 51.85 \\
\hline p5 - p10 & 4 & 7.41 \\
\hline $\mathrm{p} 10-\mathrm{p} 95$ & 21 & 38.89 \\
\hline$>\mathrm{p} 95$ & 1 & 1.85 \\
\hline \multicolumn{3}{|c|}{ Triceps skin fold } \\
\hline$<\mathrm{p} 5$ & 16 & 29.63 \\
\hline p5 - p10 & 5 & 9.26 \\
\hline $\mathrm{p} 10-\mathrm{p} 95$ & 31 & 57.41 \\
\hline$>$ p95 & 2 & 3.70 \\
\hline \multicolumn{3}{|c|}{ Upper arm muscle circumference } \\
\hline$<\mathrm{p} 5$ & 30 & 55.56 \\
\hline p5 - p10 & 3 & 5.55 \\
\hline $\mathrm{p} 10-\mathrm{p} 95$ & 18 & 33.33 \\
\hline$>\mathrm{p} 95$ & 3 & 5.56 \\
\hline \multicolumn{3}{|c|}{ Upper arm muscle area } \\
\hline$<\mathrm{p} 5$ & 33 & 61.11 \\
\hline p5 - p10 & 3 & 5.55 \\
\hline $\mathrm{p} 10-\mathrm{p} 95$ & 17 & 31.49 \\
\hline$>$ p 95 & 1 & 1.85 \\
\hline \multicolumn{3}{|c|}{ Upper arm fat area } \\
\hline$<\mathrm{p} 5$ & 19 & 35.19 \\
\hline $\mathrm{p} 10-\mathrm{p} 95$ & 32 & 59.26 \\
\hline$>\mathrm{p} 95$ & 3 & 5.55 \\
\hline
\end{tabular}

$\mathrm{n}$ : number of patients. age, using Brooks et al. reference. We also found $22.22 \%$ below the 25 th percentile for weight. In the parameters indicating lean body mass, such as upper arm circumference, upper arm muscle circumference, and upper arm muscle area, more than half of the children presented depletion and preserved fat mass according to the parameters indicating body fat mass, such as triceps skin fold and upper arm fat area.

Table 2 shows the association between the specific growth curves for $\mathrm{CP}$ and the Z-Score calculation for weight that was performed using the growth patterns of the World Health Organization (WHO). There was significant difference, with $P<0.0001$ (Fisher's exact test); kappa $=0.8276$ (CI95\%:0.5983-1.0000).

TABLE 2. Association between the reference curve (Brooks et al., 2011) and the Z-Score calculation for weight, according to parameters of the WHO.

\begin{tabular}{|c|c|c|c|c|c|c|}
\hline & & ssifica & $\begin{array}{l}\text { ion of } \\
\text { Brool }\end{array}$ & $\begin{array}{l}\text { ight pe } \\
\text { urve * }\end{array}$ & centi & \\
\hline & $\begin{array}{l}\text { Lov } \\
f\end{array}$ & $\begin{array}{l}\text { ight } \\
\text { ge }\end{array}$ & $\begin{array}{r}\text { Ac } \\
\text { weig }\end{array}$ & $\begin{array}{l}\text { late } \\
\text { or age }\end{array}$ & $\mathrm{Hig}$ & $\begin{array}{l}\text { eight } \\
\text { ge }\end{array}$ \\
\hline $\begin{array}{l}\text { Classification } \\
\text { for Weight }\end{array}$ & $\mathrm{n}$ & $\%$ & $\mathrm{n}$ & $\%$ & $\mathrm{n}$ & $\%$ \\
\hline Thinness & 3 & 100 & 2 & 14.3 & 0 & 0 \\
\hline Eutrophy & 0 & 0 & 12 & 85.7 & 0 & 0 \\
\hline Obesity & 0 & 0 & 0 & 0 & 3 & 100 \\
\hline
\end{tabular}

$\mathrm{n}$ : number of patients. Thinness $=\mathrm{Z}$-Score $<-2 \mathrm{SD}$. Eutrophy $=\mathrm{Z}$-Score $\geq-2 \mathrm{SD}$ and $\leq+1 \mathrm{SD}$. Obesity $=$ Z-Score $>+2$ SD. $P<0.0001$ (There was significant difference $P<0.05-$ Fisher's exact test); kappa $=0.8276\left(\mathrm{CI}_{95 \%}: 0.5983-1.0000\right)$. $*$ Values calculated only for children under 10 years, as proposed by the WHO, 2006

Table 3 shows the values of association between the specific growth curves for cerebral palsy and the Z-Score calculation for BMI. There was significant difference, with $P<0.0001$ (Fisher's exact test); kappa=0.5689 (CI95\%:0.3509-0.7868).

TABLE 3. Association between the reference curve (Brooks et al., 2011) and the Z-Score calculation for BMI, according to parameters of the WHO.

\begin{tabular}{lccccccc}
\hline & \multicolumn{5}{c}{$\begin{array}{c}\text { Classification of percentile of } \\
\text { Brooks curve }\end{array}$} \\
\cline { 2 - 7 } & Low weight & Eutrophy & $\begin{array}{c}\text { Overweight } \\
\text { and obesity }\end{array}$ \\
\hline $\begin{array}{l}\text { Z-Score Classification } \\
\text { for BMI }\end{array}$ & $\mathbf{n}$ & $\%$ & $\mathbf{n}$ & $\%$ & $\mathbf{n}$ & $\%$ \\
\hline Thinness & 12 & 100 & 4 & 10 & 0 & 0 \\
Eutrophy & 0 & 0 & 29 & 74 & 0 & 0 \\
Obesity & 0 & 0 & 6 & 15 & 3 & 100 \\
\hline
\end{tabular}

$\mathrm{n}=$ number of patients. Thinness $=\mathrm{Z}$-Score $<-2$ SD. Eutrophy $=\mathrm{Z}$-Score $\geq-2 \mathrm{SD}$ and $\leq+1 \mathrm{SD}$. Obesity $=$ Z-Score $>+2$ SD. $P<0.0001$ (There was significant difference $P<0.05-$ Fisher's exact test); kappa $=0.5689\left(\mathrm{CI}_{95 \%}: 0.3509-0.7868\right)$

Table 4 shows the data on the association between the specific growth curves for cerebral palsy and the Z-Score calculation for height. We observed that, for weight and BMI, the kappa index (close to 1$)$ and the value of $P(<0.05)$ indicate a good agreement and association between the curves, a fact that was not verified in height, which showed low correlation between the curves. 
TABLE 4. Association between the reference curve (Brooks et al., 2011) and the Z-Score calculation for height, according to parameters of the WHO.

\begin{tabular}{|c|c|c|}
\hline & \multicolumn{2}{|c|}{$\begin{array}{c}\text { Classification of percentile of } \\
\text { Brooks curve }\end{array}$} \\
\hline & \multicolumn{2}{|c|}{ Adequate height for age } \\
\hline Z-Score Classification for Height & $\mathrm{n}$ & $\%$ \\
\hline Very low height for age & 18 & 33.33 \\
\hline Low height for age & 16 & 29.63 \\
\hline Adequate height for age & 20 & 37.04 \\
\hline
\end{tabular}

$\mathrm{n}$ : number of patients. Very low height for age $=\mathrm{Z}$-Score $<-3 \mathrm{SD}$. Low height for age $=$ $\mathrm{Z}$-Score $\geq-3 \mathrm{SD}$ and $<-2 \mathrm{SD}$. Adequate height for age $=\mathrm{Z}$-Score $\geq 2 \mathrm{SD}$.

\section{DISCUSSION}

We found low weight in $22 \%$ of the studied patients, using the specific growth curves for patients with SQCP. As they are patients with SQCP, this rate was higher than that described by Araújo and Silva $(2013)^{(1)}$, of $10 \%$, which covers various degrees of severity of CP. More than half of the patients presented the parameters indicating lean mass below the 5 th percentile. The height of all patients was classified as adequate for the age by the reference curve.

Krick et al. (1996) ${ }^{(12)}$ and Day et al. (2007) $)^{(5)}$, in their studies, built specific curves for children with $\mathrm{CP}$ and classified fewer individuals as bearers of nutritional deficit, compared to NCHS classifications $^{(5,12)}$. These results were also found in this study. Another point of disagreement was the classification of height as adequate for age in $100 \%$ of patients, defined by the specific growth curves for cerebral palsy, while the Z-Score indicate low or very low height for age. Weight and BMI indexes show a good agreement between the curves, but the height index showed a bad agreement, which can be related to the fact that the height was estimated by kneeheight, a measurement of difficult assessment and that may not match accurately the height when measured in standing position.

Brooks et al. (2011) ${ }^{(2)}$ conducted a study to classify the nutritional status according to the patient's motor performance by the evaluation of individuals with $\mathrm{CP}$, which were used in this study. Other authors have shown the need for the use of specific curves for SQCP, since these children present a different growth from healthy children, being smaller, but do not present nutritional deficit related to losses, consumption, or low nutrient intake $\mathrm{e}^{(2,15,22)}$. In this study, we found $22.22 \%$ below the 25 th percentile for weight, however, it is important to note that, even when properly nurtured, children with CP present muscle atrophy, possibly due to physical inactivity, mechanical forces exerted on bones, joints, and muscles, endocrine factors, in addition to higher prevalence of prematurity and low birth weight than the general population, which also makes them be usually smaller than healthy children ${ }^{(10)}$.

The measurement of skin folds is an important instrument in the nutritional assessment of patients with Spastic Quadriplegic CP. The triceps or subscapular skin folds provide useful information of fat mass, and the TSF is the best tool for evaluation of malnutrition in children with $\mathrm{SQCP}^{(21)}$.

Muscle mass can be estimated using mathematical equations to this end ${ }^{(8)}$. Although most patients were classified as eutrophic according to weight and BMI, more than half presented the parameters indicative of lean mass below the 5th percentile, showing depletion $(\mathrm{UAC}=51.85 \%$; UAMC $=55.56 \%$; UAMA $=61.11 \%)$, while the parameters indicative of fat mass were between the 10th and 95 th percentiles, showing conservation $(\mathrm{TSF}=57.41 \%$ and $\mathrm{UAFA}=59.26 \%$ ). These findings may be related to the limited mobility and lack of physical activity of these patients, generating little stimulus for muscle forming. Thus, it is clear that children with SQCP have greater tendency to show reduced muscle mass and increased fat mass when compared to healthy children ${ }^{(24)}$.

Low food intake in these patients seems to be associated with a number of factors, highlighting predominantly the swallowing disorders and higher incidence of gastrointestinal disorders. In addition, there are factors associated with the difficulties of caregivers to feed them properly. Caring for a chronically disabled child and with feeding difficulties requires efforts of social, emotional, financial, and familiar nature, not always available ${ }^{(19)}$.

Recognizing that the anthropometric aspects of children with SQCP differ from those of healthy children is essential to the good clinical practice in the care of these cases. All children with this diagnosis need individualized nutritional assessment and prescription, a task that must recognize any deficits and identify plausible goals. We recommend the use of specific curves, including measurements of triceps skin fold and upper arm circumference in the clinical evaluation, since they are easy, low-cost methods, and additives for the appropriate nutritional diagnosis.

\section{ACKNOWLEDGMENTS}

To the Espaço da Escrita/Coordenadoria Geral da UNICAMP for the contributions with the translation and CAPES or the financing of the project.

\section{Authors' contributions}

Caselli TB: lead researcher and article author. Lomazi EA: contribution with correction. Montenegro MAS: help in obtaining data. Bellomo-Brandão MA: project supervisor. 
Caselli TB, Lomazi EA, Montenegro MAS, Bellomo-Brandão MA. Métodos de avaliação do estado nutricional de crianças e adolescentes com Paralisia Cerebral Tetraespástica. Arq Gastroenterol. 2017;54(3):201-5.

RESUMO - Contexto - Devido a diversos fatores, como doenças do trato gastrointestinal e dificuldade de alimentação, frequentemente crianças com Paralisia Cerebral Tetraespástica apresentam prejuízo no estado nutricional. Objetivo - Avaliar o estado nutricional de pacientes pediátricos com Paralisia Cerebral Tetraespástica de acordo com curvas de referência para essa população e comparar com as curvas de referência utilizadas para a população pediátrica em geral. Métodos - Foram obtidos os dados de: altura do joelho, estatura estimada, peso, circunferência braquial e dobra cutânea triciptal. Valores de dobras e circunferências foram comparados com Frisancho e curvas específicas para esses pacientes foram utilizadas como referência. A relação entre os valores plotados na curva de crescimento para crianças saudáveis, Escore- $Z$ e comparação com a curva referencial foram verificados através do teste exato de Fisher. O nível de significância adotado foi de 5\%. Resultados - Foram avaliados 54 pacientes. A média de idade foi de 10,2 anos, 34 eram do sexo masculino. Vinte cinco se alimentavam via gastrostomia e 29 via oral. A frequência de baixo peso pela curva referencial foi de 22,22\%. Mais da metade dos pacientes apresentaram os parâmetros indicativos de massa magra abaixo do percentil 5 . A estatura de todos os pacientes foi classificada como adequada para idade pela curva referencial. Conclusão - O baixo peso foi encontrado em $22 \%$ dos pacientes, e há maior tendência para que esses pacientes apresentem massa muscular reduzida e aumento da massa gorda, mostrando a necessidade de avaliação e intervenções apropriadas para pacientes com Paralisia Cerebral Tetraespástica.

DESCRITORES - Paralisia cerebral. Quadriplegia. Avaliação nutricional.

\section{REFERENCES}

1. Araújo LA, Silva LR. Anthropometric assessment of patients with cerebral palsy: which curves are more appropriate? J Pediatr. 2013;89:307-14.

2. Brooks J, Day S, Shavelle R, Strauss D. Low weight, morbidity, and mortality in children with cerebral palsy: new clinical growth charts. Pediatrics. 2011;128:299-307.

3. Caram ALA, Morcillo AM, Pinto EALC. Estado nutricional de crianças com Paralisia Cerebral. Rev Nutr. 2010;23:211-19.

4. Chumlea C, Guo SS, Steinbaugh ML. Prediction of stature from knee height for black and white adults and children with application to mobility-impared or handicapped persons. Journal of the American Dietetic Association. 1994;94:1385-91.

5. Day SM, Strauss DJ, Vachon PJ, Rosenbloom L, Shavelle RM, Wu YW. Growth patterns in a population of children and adolescents with cerebral palsy. Develop Med Child Neurol. 2007;49:167-71.

6. Diament A. Encefalopatias crônicas na infância (paralisia cerebral). In: Diament A, Cypel S. Neurologia infantil. 3 ed. São Paulo: Atheneu; 1996. p.781-98.

7. Frisancho AR. Anthropometric standards for the assessment of growth and nutrition status. Ann Arbor: University of Michigan Press; 1993.

8. Frisancho AR. New norms of upper limb fat and muscle areas for assessment of nutritional status. Am J Clin Nutr. 1981;34:2540-5.

9. Fung EB, Samson-Fang MD, Stallings MD, Conaway M, Liptak MD, Henderson $\mathrm{RC}$, et al. Feeding dysfunction is associated with poor growth and health status in children with cerebral palsy. J Am Diet Assoc 2002;102:361-73.

10. Henderson RC, Grossberg RI, Matuszewski J, Menon N, Johson J, Kecskemethy $\mathrm{HH}$, et al. Growth and nutritional status in residential center versus home-living children and adolescents with quadriplegic cerebral palsy. J Pediatr. 2007;151:161-6.

11. Himmelmann K, Beckung E, Hagberg G, Uvebrant P. Gross and fine motor function and accompanying impairment in cerebral palsy. Dev Med Child Neurol. 2006;48:417-23.

12. Krick, J, Miller MP, Zeger S, Weight E. Pattern of growth in children with cerebral palsy. J Am Diet Assoc. 1996;96:680-5.

13. Marchand V, Motil, K. NASPGHAN Comitee on Nutrition. Nutrition support for neurologically impaired children: a clinical report of the North American Society for Pediatric Gatroenterology, Hepatology, and Nutrition. J Pediatr Gastroenterol Nutr. 2006;43:123-35.

14. Morton RE, Bonas R, Fourie B, Minford J. Videofluoroscopy in the assessment of feeding disorders of children with neurological problems. Develop Med Child Neurol. 1993;35:388-95.
15. Mota MA, Silveira CRM, Mello ED. Crianças com paralisia cerebral: como podemos avaliar e manejar seus aspectos nutricionais. International Journal of Nutrology. 2013;6:60-8.

16. Oeffinger D, Bagley A, Rogers S, Gorton G, Kryscio R, Abel M, et al. Outcome tools used for ambulatory children with cerebral palsy: responsiveness and minimum clinically important differences. Dev Med Child Neurol. 2008;50: 918-25.

17. Patrick J, Gisel E. Nutrition for the feeding impaired child. J Neuro Rehab. 1990;4:115-19.

18. Rieken R, Goudoever JB, Schierkeek H, Willemsen SP, Calis EAC, Tibboel D, et al. Measuring body composition and energy expenditure in children with severe neurologic impairment and intellectual disability 1-3. Am J Clin Nutr. 2011;94:759-66.

19. Rouse L, Herrington P, Assey J, Baker R, Golden S. Feeding problems, gastrostomy and families: a qualitative pilot study. BILD. 2002;30:122-8.

20. Samson-Fang L, Stevenson RD. Linear growth velocity in children with cerebral palsy. Dev Med Child Neurol. 1998;40:689-92.

21. Samson-Fang LJ, Stevenson RD. Identification of malnutrition in children with cerebral palsy: poor performance of weight-for-height centiles. Develop Med Child Neurol. 2000;42:162-8.

22. Stevenson RD, Conaway M, Chumlea WC, Rosenbaum P, Fung EB, Henderson $\mathrm{RC}$, et al. Growth and health in children with moderate-to-severe cerebral palsy. Pediatrics. 2006;118:1010-8.

23. Stevenson RD. Use of segmental measures to estimate stature in children with cerebral palsy. Arch Pediatr Adolesc Med. 1995;149:658-62.

24. Sullivan PB, Alder N, Bachlet AME, Grant H, Juszczak E, Henry, J, et al. Gastrostomy feeding in cerebral palsy: too much of a good thing? Dev Med Child Neurol. 2006;48:877-82.

25. Venkateswaran S, Shevell MI. Comorbidities and clinical determinants of outcome in children with spastic quadriplegic cerebral palsy. Dev Med Child Neurol. 2008;50:216-22.

26. Veugelers R, Benninga MA, Calis EA, Willemsen SP, Evenhuis H, Tibboel D, et al. Prevalence and clinical presentation of constipation in children with severe generalized cerebral palsy. Dev Med Child Neurol. 2010;52:216-21.

27. World Health Organization (WHO). WHO Child Growth Standards: Lenght/ height-for-age, weight-for-length, weight-for-height and body mass index-for-age. Methods and development. WHO (nonserial publication), 2006. 